\title{
A Logical Approach To Teaching Accounting For Derivatives
}

Arlette C. Wilson, (Email: awilson@business.auburn.edu), Auburn University Norman H. Godwin, (Email: godwin@business.auburn.edu), Auburn University

\section{INTRODUCTION}

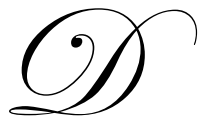

erivatives are financial instruments designed to achieve a certain economic result when an underlying security, rate, index, commodity, or other financial instrument moves in a given direction. A derivative derives its value from movements in the underlying instrument on which the derivative is based. Many companies have effectively used derivatives to help manage financial risks such as security price risk, interest rate risk, commodity price risk, or foreign currency exchange rate risk. During the 1990's, the derivatives market experienced tremendous growth in response to the complex risk profiles of many companies. But with this growth came some high profile, derivative losses exposing the inadequacies of the financial reporting of derivatives.

The accounting and reporting for derivatives is governed by Statement of Financial Accounting Standards No. 133 "Accounting for Derivative Instruments and Hedging Activities" (FASB 133). Prior to the issuance of this standard, accounting rules were somewhat piecemeal because they developed periodically as new derivative activity developed. One of the problems with this piecemeal approach was the existence of internally inconsistent rules. For example, rules related to instruments similar in substance such as futures and forwards were accounted for very differently. To provide a comprehensive approach to accounting for all derivative instruments including those yet to be developed, FASB 133 was issued.

Although FASB 133 replaced the piecemeal approach with comprehensive guidance, many text books continue to cover derivative accounting in a piecemeal fashion. Authors have updated the text material to reflect the new rules, but they have not provided a comprehensive approach to teaching this material. This paper will provide a logical and comprehensive approach to teaching the accounting for basic derivatives and hedging activities.

\section{GENERAL APPROACH}

In order for a student to understand the accounting for derivatives, he needs to understand three main issues. First, he should know how the financial instruments derive their value and how they are settled. Second, he should understand how these instruments can be used as effective hedges for risk management purposes. Once he understands the functioning of these instruments and the hedges, he is ready to tackle the third issue of the accounting for derivatives. Thus, our general approach to teaching accounting for derivatives includes:

- $\quad$ Identifying and explaining the basic derivatives and how they function.

- $\quad$ Explaining how these derivatives can function as effective hedges of risk exposure.

- $\quad$ Explaining the general accounting for derivatives.

Our paper follows this approach, starting with a description of the basic types of derivatives.

\section{BASIC DERIVATIVES}

Although derivatives can be designed in very complex ways, there are four basic derivatives commonly used for risk management. These derivatives are: 


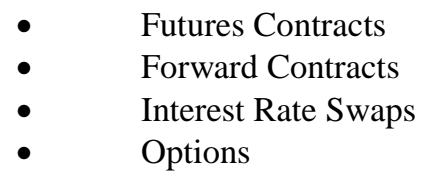

Each of these contracts should be explained to the student.

\section{Futures Contract}

A futures contract is an exchange-traded legal contract to buy or sell a standard quantity of a commodity, financial instrument, or index at a specified future date for a price specified today. Example 1 is used to explain how a futures contract functions. In the example, Company $\mathrm{X}$ has locked-in to purchase one million widgets at $\$ 2$. If the market price of widgets declines, the futures contract is in a loss position because Company X must still purchase the widgets at the higher $\$ 2$ price. If the market price of the widgets increases above $\$ 2$, the futures contract is in a gain position for Company X. Note here that the derivative instrument derives it value from the movement of the "underlying." The underlying in this example is the market price of widgets. As the market price moves, the value of the futures contract changes.

At March 1, 2007, the market price is $\$ 2.07$. On that date, Company $\mathrm{X}$ could buy the one million widgets at $\$ 2.00$ each and then sell them in the market for $\$ 2.07$ each, making a \$70,000 profit. Instead of taking delivery, we will assume that the futures contract is cash-settled. This means that Company X will receive the difference between the locked-in purchase price of $\$ 2$ and the current price of $\$ 2.07$, or $\$ 70,000$. We will assume in this paper that all contracts are "cash-settled."

\section{Forward Contract}

A forward contract is a legal contract between two parties to purchase or sell a specific quantity of a commodity, security, foreign currency, or other financial instrument in the future at a price or rate specified now. Example 2 is used to explain how a forward contract functions. In the example, Company $\mathrm{X}$ has locked-in a sales price of $\$ 1.50$ per foreign currency unit (FCU). If the exchange rate declines, Company $\mathrm{X}$ can acquire the foreign currency for less than what it will sell it for. This results in a receive position for Company $\mathrm{X}$. If the exchange rate increases, Company $\mathrm{X}$ will pay more to acquire the currency than it will receive from selling it. Thus, Company $\mathrm{X}$ is in a pay position.

On the April 30 settlement date, the exchange rate is $\$ 1.40$ per FCU. This means that Company $\mathrm{X}$ can acquire the currency for $\$ 140,000$ on that date. The forward contract allows Company $X$ to sell the currency for $\$ 150,000$, so it is in a receive position. If the contract is cash settled, Company $\mathrm{X}$ would receive $\$ 10,000$.

\section{Interest Rate Swap}

A swap, in general, is an exchange of payment streams. An interest rate swap is a contract between two parties to exchange interest payments on a specified principal amount (referred to as notional) for a specified period. In the most common instance, a swap involves the exchange of streams of variable and fixed-rate interest payments.

Example 3 is used to illustrate the exchange of payment streams. In the example, the calculation of the net settlement each period is the difference between LIBOR at the beginning of the period and the fixed rate of 8.0 percent on a notional of $\$ 100,000,000$. For example, consider the period Jan. $1-$ June 30,2007 . For that six months, Company X would receive LIBOR of 7.9 percent on $\$ 100,000,000(\$ 3,950,000)$ and pay 8.0 percent on $\$ 100,000,000$ $(\$ 4,000,000)$. As a result, the net settlement is for Company $\mathrm{X}$ to pay $\$ 50,000$. 


\section{Options}

An option is a contract giving its owner the right, but not the obligation, to buy or sell a specific item at a fixed price (strike price) during a specified period (exercise period). An option contract normally provides the purchaser a CALL (right to buy) or a PUT (right to sell) option. The fair value of options contains two elements. The first is the intrinsic value, which is based on the degree to which the option is in-the-money. The second is the time value, which represents the market's expectation of how likely it is that the option will be valuable before it lapses. Example 4 provides an illustration of an option contract.

From Example 4, the fair value of the options at December 31 consists of $\$ 100,000$ intrinsic value and $\$ 20,000$ of time value. The intrinsic value is the amount that would be received if the option were exercised at that time. At December 31, the company could buy the stock at the market price of $\$ 19$ and exercise the option to sell at $\$ 20$, thereby making $\$ 1$ per option. Any remaining value of the options is time value. When the options expire, the fair value of the options equals the intrinsic value since there is no more time for the options and the time value is therefore zero.

One last comment on these basic derivatives before moving on to hedging activities. Futures, forwards, and swaps are two-sided derivatives. That is, the settlement of the contract could result in either a receive or pay position. Because they are two-sided, no cash is exchanged when the contract is entered into. Only when the contract is settled is cash exchanged. In contrast, options are one-sided derivatives. The holder exercises the options only when he is in a receive position. For this right, the holder must pay a premium. Thus, the buyer of an option pays a nonrefundable fee to the seller.

\section{HEDGING OF RISK EXPOSURE}

Derivatives play a key role in today's risk management strategies since they are valuable tools for managing or adjusting specific risks. It is important to understand how companies use derivatives in their risk management strategies in order to understand how we account for these activities.

\section{Commodity Price Risk}

Companies that use or produce commodities are exposed to the risk of changing prices. Futures contracts can be used to lock-in the purchase or selling price of those commodities. Example 5 provides a commodity risk exposure. The purchase price of widgets is "locked-in" at $\$ 2.00$ with the futures contract. On March 1, 2007 Company X purchases widgets in the normal market channels for \$2.07 each and cash settles the futures contract as follows:
$\$ 1,000,000$ widgets at $\$ 2.07$
$\$ 2,070,000$ outflow
Cash-settlement futures
Net Cash Flow
$\frac{70,000}{\$ 2,000,000}$ inflow

The futures contract was an effective hedge in fixing the purchase price at $\$ 2.00$ per widget.

\section{Foreign Currency Exchange Rate Risk}

Companies that purchase and sell with the price denominated in a currency other than the US dollar are exposed to the risk of changing exchange rates. Forward contracts can be used to lock-in the exchange rate. Example 6 provides a foreign currency exchange rate risk exposure. The exchange rate is "locked-in" at $\$ 1.50$ per FCU. On April 30, 2006, Company X receives the foreign currency and exchanges it for US dollars and cash-settles the forward contract as follows: 
100,000 FCU@ @1.40

Cash settlement forward contract

Net Cash Flow

$$
\begin{array}{r}
\$ 140,000 \text { inflow } \\
10,000 \text { inflow } \\
\$ 150,000 \text { inflow }
\end{array}
$$

The forward contract was an effective hedge in fixing the exchange rate at $\$ 1.50$ per FCU.

\section{Interest Rate Risk}

Companies holding or expecting to hold interest-bearing investments or interest-bearing debt are exposed to the risk of changing interest rates. Interest rate swaps are one way of managing interest rate risk. Example 7 provides an interest rate risk exposure. To effectively convert its variable-rate debt to a fixed rate, the company enters into an interest rate swap whereby it receives a variable rate of LIBOR and pays a fixed rate of 8 percent. The LIBOR received through the swap plus an additional 0.5 percent is then used to service the existing 3 -year debt. The swap has effectively converted the variable-rate debt to a fixed rate of 8.5 percent ( 8 percent paid on the swap and the additional 0.5 percent needed for the debt).

\section{Security Price Risk}

Companies often have investment portfolios that include equity securities. In order to protect against unexpected price movements, the company could use equity options. Example 8 provides a security price risk exposure. The put options allow the company to sell Stock A at $\$ 20$ per share if the price were to decline below $\$ 20$. If the price of Stock A were to increase above \$20, then the company would not exercise the options and would sell the stock at market price. The options were an effective hedge to protect the gain on the stock that existed at October $1,2006$.

Note again that options protect against adverse movements while allowing the company to take advantage of beneficial movements. For this right, the company must pay for the options. The other three derivatives require no upfront exchange of cash.

\section{GENERAL ACCOUNTING FOR DERIVATIVES}

The general accounting for derivatives is as follows. All derivatives are marked to fair value at the financial statement date and reported on the financial statements as assets or liabilities. The change in fair value of the derivative (a gain or a loss) is recognized in current earnings. However, special accounting is allowed if the derivative qualifies for and is designated as a:

- fair value hedge

- $\quad$ cash flow hedge

- $\quad$ hedge of a net investment in a foreign operation.

\section{Fair Value Hedge}

A fair value hedge is any derivative hedging the exposure to changes in the fair value of a recognized asset or liability or a firm commitment. The derivative (hedging instrument) is marked to fair value with the unrealized gain or loss included in current earnings. Simultaneously, the hedged item (asset, liability, or firm commitment) is adjusted for changes in fair value attributable to the risk being hedged, with the related unrealized loss or gain included in current earnings. The effect of this accounting is to reflect in earnings the extent to which the hedge is not effective in achieving offsetting changes in fair value.

Example 9 provides an illustration of a fair value hedge. The fair value of fixed-rate debt will vary as the interest rate varies. Therefore, the debt has fair value exposure. The interest rate swap hedges the fair value exposure by effectively converting the fixed-rate debt to variable-rate debt. 
On December 31, 2006, three entries are required. The first is the payment of interest on the fixed rate debt. The second and third entries are both adjusting entries. The second is the marking of the SWAP to its fair value with the gain included in current earnings. The third is the adjustment of the debt to its higher fair value resulting from the decrease in the interest rate. The loss from the adjustment is included in current earnings. Note that the gain on the swap and the loss on the fair value of the debt are a perfect offset. Notice also that because LIBOR was equal to 8 percent on January 1, there is no swap settlement to record on December 31.

FASB allows the "short-cut method" if all the critical terms are matched as follows:

- $\quad$ Principal and notional the same

- $\quad$ Payment and settlement dates the same

- $\quad$ Maturity dates the same

The "short-cut method" assumes that hedge ineffectiveness is zero unless credit worthiness of some of the parties has significantly changed. No hedge ineffectiveness means that change in the value of the hedging instrument exactly offsets the change in fair value of the hedged item.

On December 31, 2007, five entries are required. The first entry records the interest expense on the debt. Interest Expense is calculated based on the carrying value of the note $(\$ 10,180,801)$ and the current interest rate $(7 \%)$. Remember that, in substance, the debt was converted to variable rate tied to LIBOR. The second entry is the swap settlement. The settlement is a cash inflow of $\$ 100,000$ because the company received 8 percent but only paid LIBOR of 7 percent.

The remaining three entries are adjusting entries. The first adjustment is to the swap account. The account was reported as an asset (receivable) at December 31, 2006 and is now increased by 7 percent, which represents interest on the receivable for 2007. Instead of recording this increase as interest revenue, it is reported as a reduction of interest expense. Remember that the swap is hedging the interest on the debt. Total interest expense for 2007 is therefore reported as $\$ 700,000$ ( $\$ 712,656$ - $\$ 12,656)$, which is the debt of $\$ 10,000,000$ and LIBOR of 7 percent.

The other two adjusting entries report the change in fair value of the debt and the swap because LIBOR has risen to 7.5 percent. The fair value of the swap is again implied based on the fair value of the debt because the "shortcut method" is being used. Examples of some other fair value hedges are included in Exhibit 1.

\section{Cash Flow Hedge}

A cash flow hedge is a derivative hedging the exposure to changes in cash flows of an existing asset or liability or of a forecasted transaction. The derivative is marked to fair value with the change in fair value included in other comprehensive income (OCI) to the extent that accumulated other comprehensive income (AOCI) is adjusted to an amount that equals the lesser of:

- the cumulative gain or loss on the derivative or

- $\quad$ the cumulative change in expected future cash flows on the hedged item or transaction.

The accumulated gains and losses are removed from AOCI and included in earnings in the same period(s) as the hedged item affects earnings. Examples of when AOCI is included in earnings are included in Exhibit 2.

Example 10 provides an illustration of a cash flow hedge. The options are initially purchased at $\$ 80,000$ and increase in value to $\$ 260,000$ by year-end. The effective part of the hedge is the amount of intrinsic value of the options. As the stock price declines, the loss of investment value is offset by the gain in intrinsic value. Therefore, the intrinsic value is reported in OCI and accumulated in stockholders' equity until the hedged item (investment) affects earnings.

The change in time value represents the ineffective part of the hedge and is included in current earnings. All $\$ 80,000$ of initial time value will be reported as a reduction of current earnings by the time the options expire. The 
intrinsic value remains in OCI until the investment is sold (hedged item affects earnings). At that time the gain is removed from AOCI and included in current earnings. Note that the gain from sale $(\$ 700,000)$ and gain from intrinsic value $(\$ 300,000)$ results in a total gain of $\$ 1,000,000$ which was the amount of the gain at the time the put options were purchased to protect the gain. However, if the investment is sold at a later date, the protection is only to October 1, 2007 and any further declines will result in less gain. Additional examples of cash flow hedges are included in Exhibit 3.

\section{Hedge of a Net Investment in a Foreign Operation}

A company that holds a net investment in a foreign operation is exposed to changes in value of that investment as exchange rates fluctuate. These changes result in translation gains and losses which are reported in OCI. A derivative that hedges this exposure is referred to as a hedge of a net investment in a foreign operation. The derivative is marked to fair value with the gain or loss reported in OCI as part of the cumulative translation adjustment, but only to the extent of the loss or gain on the investment.

Example 11 provides an illustration of a hedge of a net investment in a foreign operation. The translation gain or loss on the investment, which are based on changes in the spot exchange rate, are included in OCI and accumulated in stockholders' equity until the Investment is liquidated. The gain or loss on the foreign currency forward contract is based on the change in the forward rate, discounted to reflect the time value of money until settlement date.

The change in value of the forward contract represents a gain since the foreign currency was sold at $\$ 1.60$ per FCU and could be settled by purchasing at a cheaper rate than sold for. The change in forward contract fair value is included in OCI, but is limited to the amount of translation loss associated with the net investment. The other $\$ 15,000$ for 2006 and $\$ 85,000$ for 2007 is considered ineffective and is reported in current earnings. This unrealized gain on the forward contract is accumulated in equity until the Investment is liquidated. At that time the gain is removed from equity and included in current earnings because the hedged item (Investment) affects earnings at that time (liquidation). The change in value of the Investment is offset by the forward contract only for the hedging period 2006 through 2007.

\section{CONCLUSION}

FASB provides comprehensive accounting for all derivative instruments no matter how exotically designed. They allow special accounting for those derivatives that qualify for and are designated as acceptable hedges. The basic concept of that accounting is to include the gain or loss on the derivative in the same period that the hedged item affects earnings to the extent the hedge is effective. Accounting for derivatives should reflect this comprehensive approach rather than teaching the accounting for different derivatives in different chapters as a piecemeal approach.

\section{Example 1}

\section{Futures Contract Illustration}

On November 1, 2006, Company X entered into a futures contract to purchase 1,000,000 widgets at $\$ 2$ each on March 1, 2007. The market price of widgets is \$1.95 on December 31, 2006 and \$2.07 on March 1, 2007.

- $\quad$ Unrealized Loss at December 31, $2006 \ldots \$ 50,000$

- $\quad$ Cash settlement on March 1, 2007 ... Receive \$70,000 


\section{Example 2}

\section{Forward Contract Illustration}

On March 1, 2006, Company X enters into a 60-day forward contract to sell 100,000 foreign currency units (FCU) for $\$ 1.50$ per FCU. On April 30, 2006, the exchange rate is $\$ 1.40$ per FCU. The contract is cash-settled on April 30 in which Company $X$ will receive $\$ 10,000$.

\section{Example 3}

\section{Interest Rate Swap Illustration}

On January 1, 2006, Company X enters into a 3-year interest rate swap to pay a fixed rate of 8 percent and receive LIBOR (London Interbank Offer Rate) on a notional of $\$ 100,000,000$. Rate reset and settlement are semiannually on June 30 and December 31.

\begin{tabular}{|c|c|c|}
\hline Period & LIBOR at Beginning of Period & Cash Received < Paid $>$ End of Period \\
\hline Jan. 1 - June 30, 2006 & $8.0 \%$ & $\$ 0$ \\
\hline July 1 - Dec. 31, 2006 & $7.6 \%$ & $<\$ 200,000>$ \\
\hline Jan. 1 - June 30, 2007 & $7.9 \%$ & $<\$ 50,000>$ \\
\hline July 1 - Dec. 31, 2007 & $8.2 \%$ & $\$ 100,000$ \\
\hline Jan. 1 - June 30, 2008 & $8.5 \%$ & $\$ 250,000$ \\
\hline July 1 - Dec. 31, 2008 & $7.8 \%$ & $<\$ 100,000>$ \\
\hline
\end{tabular}

\section{Example 4}

\section{Option Illustration}

On October 1, 2006, Company X purchases PUT options on 100,000 shares of Stock A for $\$ 30,000$. The strike price is $\$ 20$ per share. The exercise period is October 1, 2006 to March 31, 2007. Market price of Stock A was $\$ 19$ at December 31, 2006, and $\$ 18.50$ at March 31, 2007. Fair value of the options was $\$ 120,000$ on December 31, 2006. The options are cash-settled on March 1, 2007 for $\$ 150,000$

\section{Example 5}

\section{Commodity Price Risk Exposure}

On November 1, 2006, Company X estimates that it will need 1,000,000 widgets for production of gadgets around the first part of March 2007. Company X has already contracted for the sale of its gadgets and any increase in the cost of widgets would reduce Company X's profit margin. To hedge this commodity price risk exposure, Company $\mathrm{X}$ enters into the futures contract from Example 1.

\section{Example 6}

\section{Foreign Currency Exchange Rate Risk Exposure}

On March 1, 2006, Company X sells merchandise to Company Foreign for 100,000 FCU for which payment is due in 60 days. To hedge this foreign currency exchange rate risk exposure, Company $\mathrm{X}$ enters into the forward contract from Example 2. 


\section{Example 7}

\section{Interest Rate Risk Exposure}

On January 1,2006 , Company $\mathrm{X}$ is currently holding $\$ 100,000,000$ of 3 -year debt tied to LIBOR $+.5 \%$. Interest payments and rate reset are semiannually on June 30 and December 31. Preferring to hold fixed-rate debt, Company $\mathrm{X}$ enters into the interest rate swap in Example 3.

\section{Example 8}

\section{Security Price Risk Exposure}

On October 1, 2006, Company X is holding 100,000 shares of Stock A originally purchased at $\$ 15$ per share, but currently selling for $\$ 20$ per share. The company plans on holding this stock to meet certain dividend requirements of the portfolio even though the price of the stock may decline. To hedge this security price risk exposure, Company X purchases the put options in Example 4.

\section{Example 9}

\section{Accounting for a Fair Value Hedge}

On January 1, 2006, Company $\mathrm{X}$ is holding $\$ 10,000,000$ of $8 \%$ debt which will mature in 3 years. Preferring to have variable-rate debt, on January 1, 2006, Company X enters into a 3-year interest rate swap to receive $8 \%$ and pay LIBOR on a notional of $\$ 10,000,000$ with rate reset and settlement annually at December 31 .

\begin{tabular}{|c|c|c|c|}
\hline Date & LIBOR & FV of Debt & Implied FV of Swap \\
\hline Jan. 1, 2006 & $8 \%$ & $\$ 10,000,000$ & -- \\
\hline Dec. 31, 2006 & $7 \%$ & $\$ 10,180,801$ & $\$ 180,801$ \\
\hline Dec. 31, 2007 & $7.5 \%$ & $\$ 10,046,511$ & $\$ 46,511$ \\
\hline
\end{tabular}

\begin{tabular}{|c|c|c|c|c|c|}
\hline \multirow[t]{6}{*}{ Dec. 312006} & Interest Exp & 800,000 & \multirow[t]{5}{*}{ Dec. 312007} & Interest Exp & 712,656 \\
\hline & \multirow[t]{4}{*}{ Cash } & \multirow[t]{4}{*}{800,000} & & Prem N/Pay & 87,344 \\
\hline & & & & Cash & 800,000 \\
\hline & & & & Cash & 100,000 \\
\hline & & & & Swap & 100,000 \\
\hline & & & Adj & Swap & 12,656 \\
\hline & & & & Interest Exp & 12,656 \\
\hline Adj & Swap & 180,801 & Adj & Loss $(\mathrm{I} / \mathrm{S})$ & 46,946 \\
\hline & Gain (I/S) & 180,801 & & Swap & 46,946 \\
\hline$\overline{\mathrm{Adj}}$ & Loss $(\mathrm{I} / \mathrm{S})$ & 180,801 & Adj & Prem N/Pay & 46,946 \\
\hline & Prem N/Pay & 180,801 & & Gain & 46,946 \\
\hline
\end{tabular}

\section{Example 10}

\section{Accounting for a Cash Flow Hedge}

On November 1, 2006, Company X holds 100,000 shares of Stock A which was purchased at $\$ 40$ per share with a current market price of $\$ 50$. The company plans on selling the stock in quarter 4 of 2007 . To protect the current gain, on November 1, 2006, Company X purchases put options on 100,000 shares of Stock A with a strike price of $\$ 50$. The options cost $\$ 80,000$ and mature on October 1, 2007. At December 31, 2006, the stock had a 
market price of $\$ 48$ and the options had a fair value of $\$ 260,000$. The stock is sold on October 1, 2007 for $\$ 47$. The options are designated as a cash flow hedge of the forecasted sale of Stock A.

\begin{tabular}{|c|c|c|c|c|c|}
\hline \multirow[t]{3}{*}{ Nov. 12006} & & & \multirow[t]{8}{*}{ Oct. 12007} & Options & 40,000 \\
\hline & Options & 80,000 & & Loss (I/S) & 60,000 \\
\hline & Cash & 80,000 & & Gain $(\mathrm{OCI})$ & 100,000 \\
\hline \multirow{5}{*}{ Dec. 312006} & Options & 180,000 & & Cash & $4,700,000$ \\
\hline & Loss $(\mathrm{I} / \mathrm{S})$ & 20,000 & & Investment & $4,000,000$ \\
\hline & Gain $(\mathrm{OCI})$ & 200,000 & & Gain (I/S) & 700,000 \\
\hline & & & & Gain (OCI) & 300,000 \\
\hline & & & & Gain (I/S) & 300,000 \\
\hline
\end{tabular}

\section{Example 11}

\section{Accounting for a Hedge of a Net Investment in a Foreign Operation}

On January 1, 2006, Company X has a 1,000,000 FCU (foreign currency units) net investment in a foreign operation. To hedge this net investment, Company X enters into a 2-year foreign currency forward contract to sell $1,000,000 \mathrm{FCU}$ at a fixed rate of $\$ 1.60$ per FCU. The contract is at market; therefore no cash is exchange at inception of the contract. Spot rates, forward rates, and fair value of the contract are as follows:

\begin{tabular}{|l|c|c|c|c|}
\hline Date & Spot Rate & Forward Rate & Translation (Gain) Loss for Year & Dec. 31 Fair Value \\
\hline Jan. 1, 2006 & $\$ 1.50 / \mathrm{FCU}$ & $\$ 1.60 / \mathrm{FCU}$ & -- & -- \\
\hline Dec. 31, 2006 & $\$ 1.44 / \mathrm{FCU}$ & $\$ 1.52 / \mathrm{FCU}$ & $\$ 60,000$ & $\$ 75,000$ \\
\hline Dec. 31, 2007 & $\$ 1.42 / \mathrm{FCU}$ & -- & $\$ 20,000$ & $\$ 180,000$ \\
\hline
\end{tabular}

\begin{tabular}{|l|l|l|}
\hline \multirow{4}{*}{ Dec. 31 2006 } & Cumulative Translation Adj. & 60,000 \\
\cline { 2 - 3 } & Investment & \multicolumn{2}{|c|}{60,000} \\
\cline { 2 - 3 } & Forward Contract & 75,000 \\
\cline { 2 - 3 } & Unreal G/L (OCI) & \multicolumn{2}{|c|}{60,000} \\
\cline { 2 - 3 } & Gain (I/S) & 20,000 \\
\cline { 2 - 3 } & Cumulative Translation Adj & 105,000 \\
\hline \multirow{4}{*}{ Dec. 31 2007 } & Investment & 20,000 \\
\cline { 2 - 3 } & Forward Contract & \\
\cline { 2 - 3 } & Unreal G/L (OCI) & \\
\cline { 2 - 3 } & Gain (I/S) & \\
\cline { 2 - 3 } & & \\
\hline
\end{tabular}

\section{Exhibit 1}

\section{Examples of Fair Value Hedges}

- Interest rate swap to receive a variable rate and pay a fixed rate to hedge fixed-rate investments.

- Futures or forward contract to buy (sell) a commodity to hedge a firm commitment to sell (buy) a commodity. 


\section{Exhibit 2}

\section{Examples When AOCI is Included in Earnings}

Hedged Item

(a) Acquisition of Raw Materials

(b) Acquisition of Equipment

(c) Interest-bearing Debt

(d) Sale of Investment
When AOCI is Reclassified

(a) Finished goods are sold

(b) Equipment is depreciated

(c) Interest expense is recorded

(d) Investment is sold

\section{Exhibit 3}

\section{Examples of Cash Flow Hedges}

- $\quad$ Futures or forward contract to hedge future purchase or sale of a commodity or currency

- Interest rate swap to receive a variable rate and pay a fixed rate to hedge variable-rate debt

- Interest rate swap to receive a fixed rate and pay a variable rate to hedge variable-rate investments.

- $\quad$ CAP to hedge variable-rate debt

- $\quad$ FLOOR to hedge variable-rate investments 